Volume 2, Nomor 1, April 2021, hlm 17-26

JTTM: Jurnal Terapan Teknik Mesin

p ISSN 2721-5377| e ISSN 2721-7825

\title{
PENERAPAN TEKNIK FAULT TREE ANALYSIS UNTUK MENGURANGI KECELAKAAN KERJA DI DEPARTEMEN REBUILD CENTER PT. $X$
}

\section{IMPLEMENTATION OF FAULT TREE ANALYSIS TECHNIQUES TO REDUCE WORK ACCIDENTS IN THE DEPARTMENT OF REBUILD CENTER PT. $X$}

\author{
Bayu Idiyanto ${ }^{1}$, Awang Surya ${ }^{2 *}$ \\ 1,2* Program Studi Teknik Mesin, Sekolah Tinggi Teknik Muhammadiyah Cileungsi \\ 1,2* Jl. Anggrek, No 25, Komplek PT.SC, Cileungsi, Bogor, Jawa Barat-Indonesia 16820 \\ *Koresponden Email: awang_surya@yahoo.com
}

\begin{abstract}
Abstrak. Kecelakaan kerja pada saat melakukan perbaikan komponen sering terjadi, namun pekerja tidak peduli dengan metode pelaksanaan pekerjaan yang dilakukan, serta menimbulkan kecelakaan kerja. Workshop Plant Rebuild Center PT X mempunyai banyak potensi kecelakaan kerja. Pada tahun 2018, terjadi 26 kasus kecelakaan kerja, di antaranya 11 kasus near miss, 9 kasus property damage, 5 first aid dan 1 LTI. Perusahaan yang telah menerapkan sistem keselamatan dan kesehatan kerja sering mengalami kecelakaan kerja. Tujuan dari penelitian ini menentukan akar masalah kecelakaan yang sering terjadi. Adapun metode yang dipergunakan dalam penelitian ini Fault Tree Analysis. Dari hasil dan pembahasan didapatkan masalah kecelakaan kerja pada teknisi. Pertama, validasi prosedur assembly turbocharger hanya dilakukan sampai pada tingkat pengawas belum sampai ke tingkat manajemen. Kedua, manajemen tidak menyadari penyebab fatigue atau kelelahan salah satunya kurang jam tidur. Ketiga, sistem sosialisasi pekerjaan terkait penggunaan APD pada di proses assembly turbocharger belum dilakukan secara sistematis. Selanjutnya dari penerapan teknik FTA pada kasus-kasus yang lain didapatkan data bahwa kecelakaan kerja berhasil ditekan untuk tahun-tahun selanjutnya.
\end{abstract}

Kata kunci: Fault Tree Analysis, Kecelakaan Kerja, APD.

Abstract. Occupational accidents when repairing components often occur, but workers do not care about the method of carrying out the work being carried out and cause work accidents. PT X's Rebuild Center Plant Workshop has many potential work accidents. In 2018, there were 26 cases of work accidents, including 11 near-miss cases, 9 property damage cases, 5 first aid cases, and 1 LTI. Companies that have implemented occupational safety and health systems often experience work accidents. The purpose of this study is to determine the root cause of accidents that often occur. The method used in this research is Fault Tree Analysis. From the results and discussion, it was found that the technician had a work accident problem. First, validation of the turbocharger assembly procedure is only carried out until the supervisory level has not yet reached the management level. Second, management is not aware of the causes of fatigue or fatigue, one of which is lack of sleep. Third, the work socialization system related to the use of PPE in the turbocharger assembly process has not been carried out systematically. Furthermore, from the application of the FTA technique in other cases, data was obtained that work accidents were successfully suppressed for the following years.

Keywords: Fault Tree Analysis, Work Accidents, PPE.

\section{PENDAhuluan}

Industri pertambangan berdasarkan sejarah dipandang sebagai lingkungan berisiko tinggi.

Meski sudah banyak perbaikan dalam hal keselamatan yang disosialisasikan kepada pelaku usaha pertambangan, tetapi banyaknya pekerja mengabaikan prosedur kerja yang 
mengakibatkan kecelakaan, seperti: kecelakaan kerja pada kendaraan operasional, longsor, pembuangan limbah yang menyebabkan dampak pada lingkungan, namun tambang yang mempunyai potensi besar adalah pertambangan batubara terhadap kecelakaan kerja. Adapun tenaga kerja harus mendapatkan perlindungan terhadap keselamatan dan kesehatan kerja untuk meningkatkan produktivitas nasional serta terjaminnya keselamatan[1].

Kecelakaan kerja suatu peristiwa yang tidak diinginkan yang merugikan terhadap manusia, merusak harta benda atau kerugian terhadap proses. Kecelakaan kerja juga dapat didefinisikan suatu kejadian yang tidak dikehendaki dan tidak diduga semula yang dapat menimbulkan korban manusia dan atau harta benda[2][3].

Data BPJS Ketenagakerjaan dalam hal kecelakaan kerja di tahun 2017 terdapat 80.392 kasus[4]. Pada industri pertambangan tahun 2016 tercatat sebanyak 146 kasus kecelakaan yang berdampak pada pekerja dengan rincian sebagai berikut: cedera ringan 59 kasus, cedera berat 71 kasus dan mati 16 kasus. Catatan kecelakaan nasional di sektor pertambangan ini memberikan gambaran bahwa industri pertambangan memang memiliki karakteristik risiko tinggi (high risk)[5]. Dalam hal kecelakaan kerja disebabkan oleh manusia dengan perilaku kerja yang tidak aman (unsafe act), serta kondisi kerja (unsafe conditions)[6][7]. Berdasarkan dari Work in Safety Environment menjelaskan 98\% disebabkan oleh unsafe act dan selebihnya unsafe condition [8]. Perilaku pekerja mempunyai peran penting dalam keselamatan dan kesehatan kerja[9].

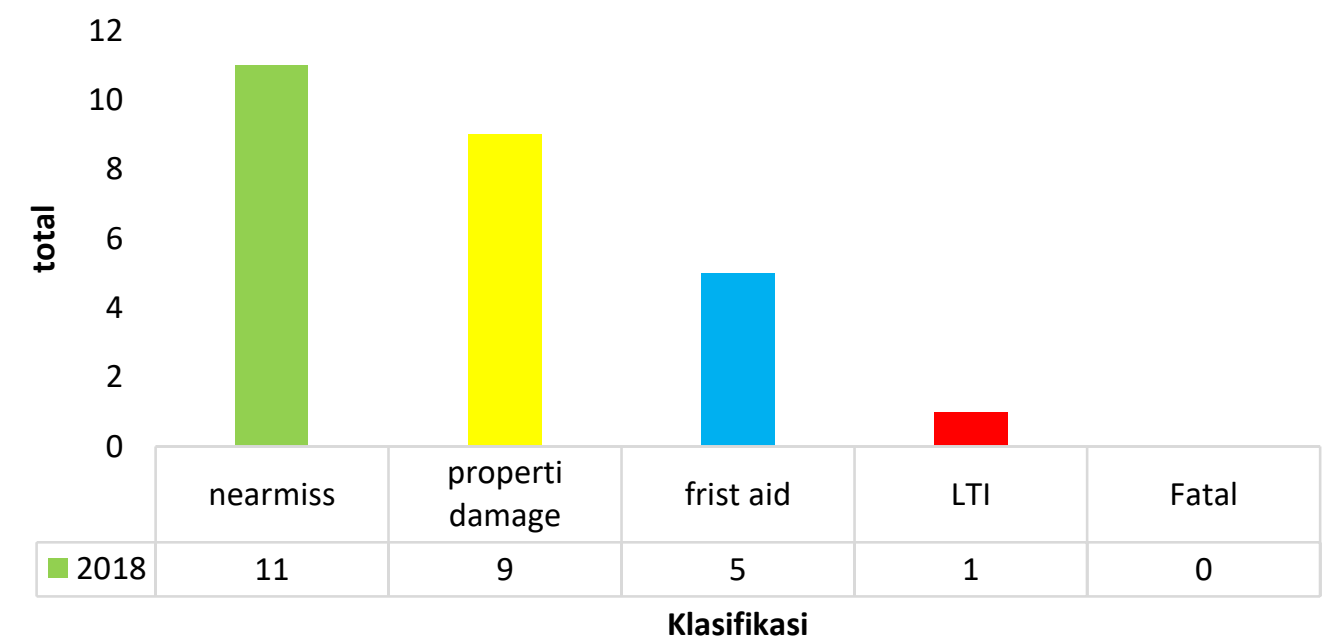

Gambar 1. Grafik total accident year to date 1 September Tahun 2018

PT. X suatu perusahaan kontraktor tambang batu bara melalui Departemen Rebuild Center, yang berlokasi di Jl. Narogong, Bekasi mempunyai komitmen untuk membuat sistem 
menyeluruh dan terintegrasi antara keselamatan, kesehatan kerja dan lingkungan. Hal ini dimaksudkan menjadi pedoman bagi manajemen dan karyawan untuk mengendalikan dan meminimalisir segala bentuk kerugian (luka karena insiden, penyakit akibat kerja, kerusakan properti dan degradasi lingkungan) di semua area kerja PT. X. Program ini diberi nama "Sapta Nirbaya” yang berisi tujuh elemen sistem untuk menuju ke zero accident.

Tetapi sistem tersebut tidak akan berjalan dengan baik bilamana beberapa faktor tidak dijalankan, seperti kasus yang terjadi di Departemen Rebuild Center PT X. Dari data Year to date sampai bulan September tahun 2018, menunjukkan angka accident terus meningkat, bila hal ini bila dibiarkan maka akan menimbulkan fatality atau kematian.

Dari gambar 1 menunjukan angka di bulan berjalan September 2018 terjadinya insiden sudah mencapai 26 kasus kecelakaan kerja, di antaranya 11 kasus near miss, 9 kasus property damage, 5 first aid dan 1 LTI (Lost Time Injury). Dari data tersebut harus dilakukan perbaikan dengan mengambil satu kejadian kecelakaan kerja agar bisa diidentifikasi akar penyebab meningkatnya angka kecelakaan kerja di PT X.

Kecelakaan menimpa karyawan yang bernama A terjadi pada tanggal 15 Agustus 2018. Kecelakaan terjadi ketika karyawan melanjutkan pekerjaan proses assembly komponen turbocharger[10]. Saat melakukan penambahan torque pada bolt turbine housing dengan menggunakan torque wrench heyco, tangan kirinya berada pada bagian housing, sedangkan tangan kanan memegang alat untuk penambahan torque. Pada saat karyawan tersebut sedang menarik tool, tiba-tiba tools terlepas dan menjepit pangkal jari jempol sebelah kiri di antara batang tools dan housing turbocharger. Kejadian tersebut menyebabkan luka pada telapak tangan kiri. Pada gambar 2 menjelaskan area kerja yang bersih sesuai dengan standar keselamatan dan kesehatan kerja.

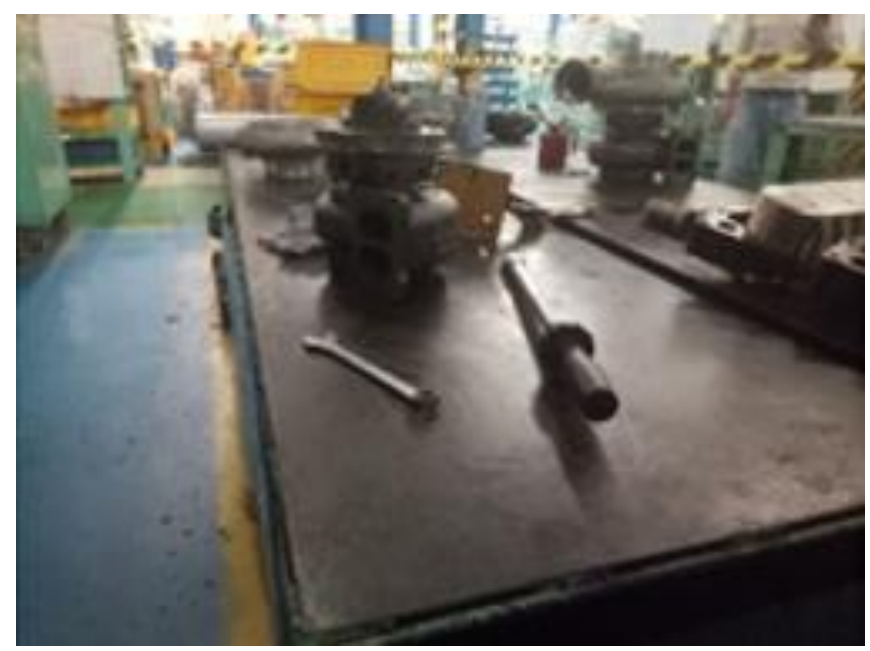

Gambar 2. Kondisi area kerja. 
Proses assembly komponen turbocharger dilakukan secara manual, tidak menggunakan peralatan khusus untuk penempatan turbocharger.

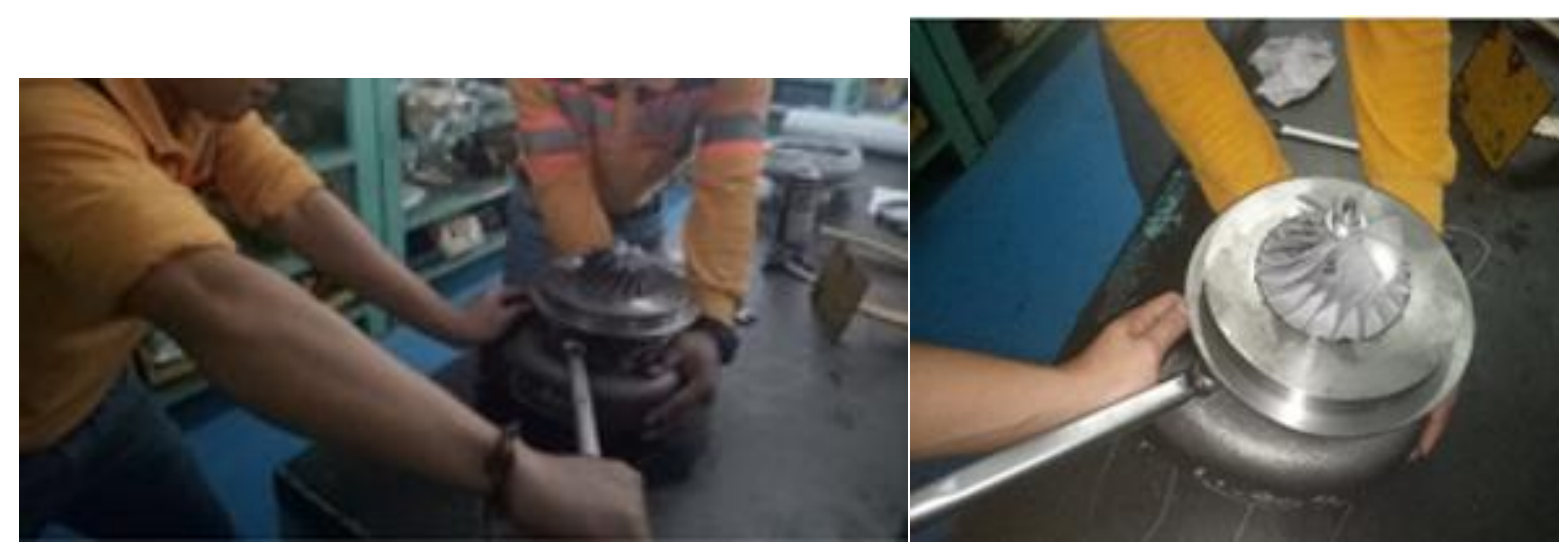

Gambar 3. Proses assembly komponen turbocharger.

Kecelakaan kerja yang terjadi pada teknisi, dimana telapak tangan kiri terjepit dengan tools.

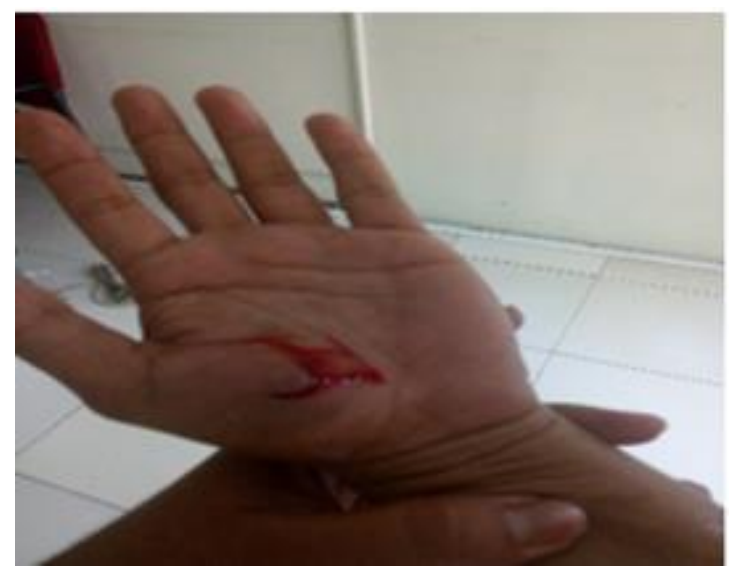

Gambar 4. Kecelakaan kerja tangan terjepit

\section{METODE}

Beberapa tahapan yang dilakukan dalam penelitian ini adalah sebagai berikut:

\subsection{Pengamatan lapangan}

Pada tahapan ini dilakukan pengumpulan data (observasi) secara langsung di lokasi kecelakaan. Kegiatan yang dilakukan adalah wawancara dengan narasumber terkait di lapangan. Selain itu juga kegiatan untuk mengumpulkan data dilakukan dengan membaca laporan kejadian di lapangan.

\subsection{Analisis dengan teknik FTA (Fault Tree Analysis)}

Untuk menganalisa kejadian ini dipergunakan teknik FTA (Fault Tree Analysis). FTA mewakili metodologi di mana seseorang menyimpulkan peristiwa masukan yang menyebabkan peristiwa keluaran[11]. FTA merupakan teknik untuk mengidentifikasikan 
kegagalan (failure) dari suatu sistem. FTA berorientasi pada fungsi atau yang lebih dikenal dengan "top down approach" karena analisa ini berawal dari system level (top) dan meneruskannya ke bawah[12]. Teknik ini menghubungkan beberapa rangkaian kejadian yang menghasilkan sebuah kejadian lain. Metode ini menggunakan pendekatan deduktif yang mencari penyebab dari sebuah kejadian. Metode ini dipakai untuk investigasi kecelakaan kerja dengan cara menganalisis penyebab langsung hingga penyebab dasar dari kecelakaan kerja itu sendiri.

\section{HASIL DAN PEMBAHASAN}

Dari pengamatan lapangan didapatkan informasi yang terangkum dalam tabel 1, posisi dimana bagian-bagian tubuh manusia yang rentan terhadap kecelakaan kerja.

Tabel 1. Rincian cedera

\begin{tabular}{|c|c|c|c|c|c|c|c|c|c|c|c|}
\hline \multicolumn{12}{|c|}{ RINCIAN CIDERA } \\
\hline & \multirow{2}{*}{ Nama } & \multicolumn{4}{|c|}{ Jenis Cidera } & \multicolumn{3}{|c|}{ Level Pen gobalan } & \multirow{2}{*}{\multicolumn{2}{|c|}{ Kincian Cidera }} & Perkiraan Hadi Hilang \\
\hline & & \multirow[t]{2}{*}{ Falal } & \multirow[t]{2}{*}{ เ1 } & \multirow[t]{2}{*}{ мп } & FAI & $\mathrm{P3K}$ & Dr & RS & & & \\
\hline & & & & & & & & & \multicolumn{2}{|c|}{$\begin{array}{l}\text { Telopok tangon ze be bh kri (da to } \\
\text { medic terlampir) }\end{array}$} & \\
\hline & & & & & & & & & & & Perkiraan Biaya \\
\hline & & & & & & & & & & & $P 0,350,00000$ \\
\hline & & & & & & & & & & & \\
\hline \multirow{6}{*}{ 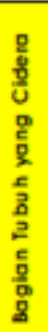 } & 1 Moto & & \multicolumn{3}{|c|}{7 Leher } & & \multicolumn{3}{|c|}{12 Lengon Bowoh } & 18 Lutut & \multirow{6}{*}{ 电 } \\
\hline & 2. Kepob & & \multicolumn{3}{|c|}{ B Bohu } & & \multicolumn{3}{|c|}{13 Tongon } & 19 Betie & \\
\hline & 3 Hidung & & \multicolumn{3}{|c|}{ f Pungeung } & & \multicolumn{3}{|c|}{14 Jaritongon } & 19 Tungkai Kaki & \\
\hline & 4 Teingo & & \multirow{2}{*}{\multicolumn{3}{|c|}{$\begin{array}{l}\text { 10 Sistem Tubuh } \\
\text { (Respiroz, jontung } \\
\text { dil) }\end{array}$}} & & \multicolumn{3}{|c|}{15 Pinggong } & 20 Telopok Ko ki & \\
\hline & 5 Pipi & & & & & & \multicolumn{3}{|c|}{ 16 Pinggul } & 21 Jarikoki & \\
\hline & 6. Bibir & & \multicolumn{3}{|c|}{11 Lengon A tor } & & \multicolumn{3}{|c|}{17 Poho } & 22 Loinnya: & \\
\hline
\end{tabular}

Tabel 2. Fakta temuan

\begin{tabular}{ll}
\hline \multicolumn{1}{c}{ ASPEK } & \multicolumn{1}{c}{ TEMUAN } \\
\hline Alat, bahan dan material & 1. Wrench torque " heyco" 17 mm (tool \\
& yang digunakan) \\
& 2. Turbocharger (part) \\
Orang & 1. Jam tidur teknisi hanya 4,5 jam \\
& 2. Masa kerja teknisi 5 tahun 4 bulan kerja \\
& di Narogong \\
& 3. Pengalaman kerja pada area serupa 3 \\
& tahun \\
Kontrol management & 1. Daftar terdapat P5M \\
& 2. Inspeksi tool \\
Prosedur Kerja & 1. Terdapat prosedur kerja INK assembly \\
& turbocharger \\
\hline
\end{tabular}


Dari data tabel 2 temuan menjadi bahan untuk membuat analisis penyebab kecelakan bisa terjadi. Sedangkan pada tabel 3 menunjukkan analisis teknik FTA.

Tabel 3. Analisis teknik FTA

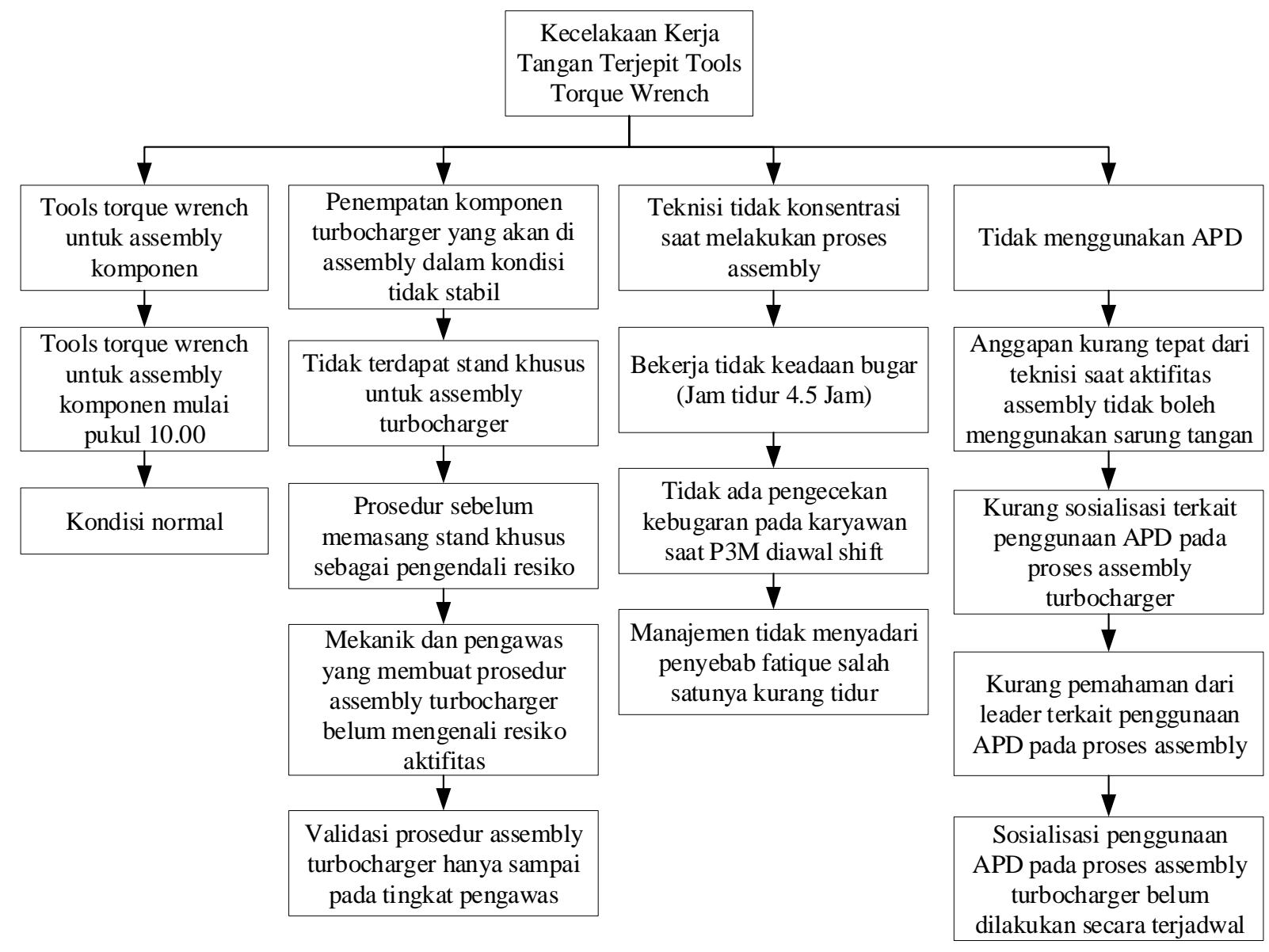

Dari analisis menggunakan metode FTA (Fault Tree Analysis) yang telah dilakukan, ditemukan bahwa akar masalah penyebab utama karyawan A mengalami kejadian tangan terjepit terdapat tiga hal dalam mengidentifikasi kecelakaan yang terjadi. Pertama, validasi prosedur assembly turbocharger hanya dilakukan sampai pada tingkat pengawas belum sampai ke tingkat manajemen. Kedua, manajemen tidak menyadari penyebab fatigue atau kelelahan salah satunya kurang jam tidur. Ketiga, sistem sosialisasi pekerjaan terkait penggunaan APD pada di proses assembly turbocharger belum dilakukan secara sistematis.

Dengan ditemukannya akar masalah maka menjadi mudah untuk mengambil tindakan perbaikannya. Tindakan yang dilakukan secara umum dibagi menjadi 3, yaitu Quick Win yaitu tindakan yang mudah dan cepat, optimize yaitu tindakan jangka menengah yang optimal dan Sustain yaitu tindakan yang berkelanjutan. Pada akar masalah yang pertama yaitu validasi prosedur assembly turbocharger hanya dilakukan sampai pada tingkat pengawas belum 
sampai ke tingkat manajemen, tindakan yang dilakukan pada tingkat Quick Win menyampaikan prosedur assembly turbocharger ke atasan terkait. Tindakan yang dilakukan pada tingkat Optimize yaitu resosialisasi atau sosialisasi ulang prosedur assembly turbocharger ke seluruh karyawan. Sedangkan tindakan Sustain ada dua tindakan, yang pertama mereview HIRA (Hazard Identification Risk Assesment) di aktivitas assembly turbocharger, dan selanjutnya menuangkan dalam bentuk JSA (Job Safety Analysis). Tindakan kedua, membuat rekayasa engineering berupa bracket stand pada aktivitas assembly turbocharger.

Tabel 4. Prosedur analisis keselamatan kerja (Job safety analysis)

\begin{tabular}{|c|c|c|}
\hline $\begin{array}{l}\text { Nomor dan Nama } \\
\text { Pekerjaan }\end{array}$ & Tanggal & NoJSA \\
\hline $\begin{array}{c}\text { Nomor dan Nama } \\
\text { Jabatan }\end{array}$ & $\begin{array}{l}\text { Disusun } \\
\text { oleh: }\end{array}$ & $\begin{array}{l}\text { Tanda } \\
\text { Tangan }\end{array}$ \\
\hline Seksi/Department & $\begin{array}{l}\text { Diperiksa } \\
\text { oleh }\end{array}$ & $\begin{array}{l}\text { Tanda } \\
\text { Tangan }\end{array}$ \\
\hline $\begin{array}{l}\text { Jabatan } \\
\text { Supervisor }\end{array}$ & $\begin{array}{l}\text { Disetujui } \\
\text { oleh: }\end{array}$ & $\begin{array}{l}\text { Tanda } \\
\text { Tangan }\end{array}$ \\
\hline \multicolumn{2}{|c|}{$\begin{array}{c}\text { Alat Pelindung Diri Yang Harus Dipakai: } \\
\text { 1. } \quad \text { Wajib digunakan, Topi safety, sepatu } \\
\text { safety, kacamata pelindung } \\
\text { 2. } \begin{array}{c}\text { Disarankan untuk menggunakan; } \\
\text { Masker debu, ear plug, sarung } \\
\text { tangan }\end{array}\end{array}$} & Lokasi kerja: Workshop assembly \\
\hline Urutan dasar langkah kerja & Resiko yang terkait & $\begin{array}{l}\text { Tindakan atau prosedur pencegahan yang } \\
\text { direkomendasikan }\end{array}$ \\
\hline $\begin{array}{l}\text { Uraikan pekerjaan tersebut } \\
\text { menjadi beberapa bagian } \\
\text { langkah kerja dasar }\end{array}$ & $\begin{array}{l}\text { Identifikasi resiko yang } \\
\text { berhubungan dengan } \\
\text { tiap-tiap langkah kerja } \\
\text { tersebut terhadap } \\
\text { kemungkinan terjadinya } \\
\text { kecelakaan }\end{array}$ & $\begin{array}{c}\text { Gunakan kedua kolom tadi sebagai pembimbing, } \\
\text { tentukan tindakan apa yang perlu diambil untuk } \\
\text { menghilangkan atau memperkecil resiko yang } \\
\text { dapat menimbulkan kecelakaan cedera atau } \\
\text { penyakit akibat kerja }\end{array}$ \\
\hline $\begin{array}{l}\text { 1. Memeriksa dan memakai } \\
\text { alat pelindung diri (APD) }\end{array}$ & 1.1 Cedera & $\begin{array}{l}\text { 1.1.1 Hanya orang dalam keadaan sehat dan sudah } \\
\text { mendapatkan pelatihan khusus dan berpengalaman } \\
\text { yang boleh melakukan pekerjaan ini. } \\
\text { 1.1.2 Alat pelindung diri (APD) harus diperiksa } \\
\text { dan dipakai dengan baik dan benar sesuai dengan } \\
\text { SOP yang berlaku }\end{array}$ \\
\hline
\end{tabular}

Pada akar masalah yang kedua yaitu manajemen tidak menyadari penyebab fatigue atau kelelahan salah satunya kurang jam tidur, tindakan Quick Win yang dilakukan mengadakan meeting koordinasi seluruh manajemen di site Narogong tempat kecelakaan terjadi untuk membahas pengendalian fatigue atau kelelahan di area kerja. Tindakan Optimize yang dilakukan adalah membuat checklist bugar selamat. Dalam checklist itu ada beberapa item yang harus dicek sebelum seorang karyawan mulai bekerja untuk memeriksa tingkat 
kebugaran seorang karyawan. Sedangkan tindakan Sustain adalah pembuatan prosedur cek fatigue pada karyawan sebelum sedang setelah bekerja.

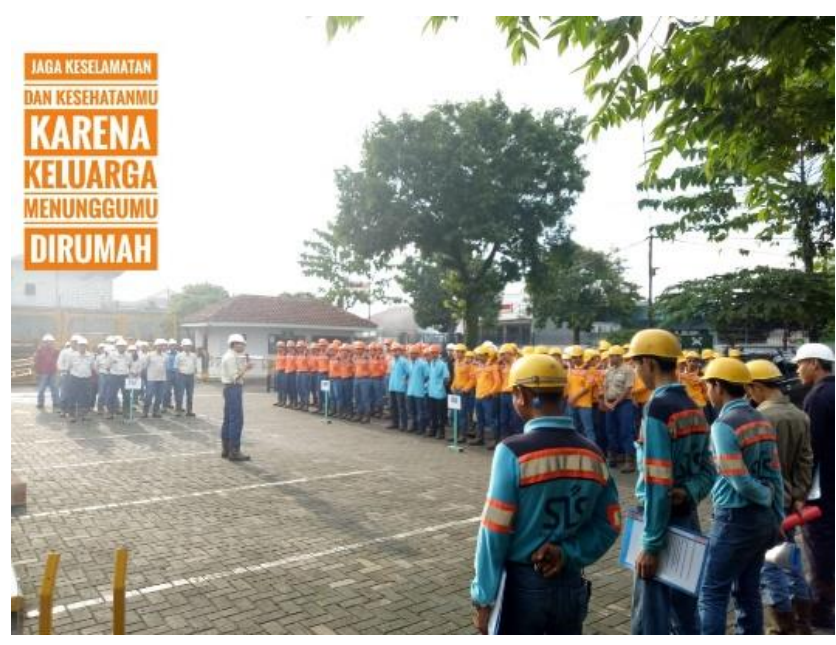

Gambar 5. Sosialisasi pentingnya APD kepada seluruh karyawan.

Pada akar masalah yang ketiga yaitu sistem sosialisasi pekerjaan terkait penggunaan APD pada proses assembly turbocharger belum dilakukan secara sistematis, tindakan Quick Win yang dilakukan adalah melakukan sosialisasi kepada seluruh karyawan terkait penggunaan APD pada aktivitas assembly. Hal ini dimaksudkan untuk meningkatkan pemahaman karyawan akan pentingnya pemakaian APD (Alat Pelindung Diri). Tindakan Optimize yang dilakukan adalah membuat monitoring bukti sosialisasi kepada karyawan. Sedangkan tindakan Sustain yang dilakukan ada dua tingkatan. Pertama, membuat prosedur sosialisasi secara sistematis dan terukur. Kedua, memastikan ketersediaan APD sesuai dengan risiko pekerjaan menggunakan metode stock minimum.

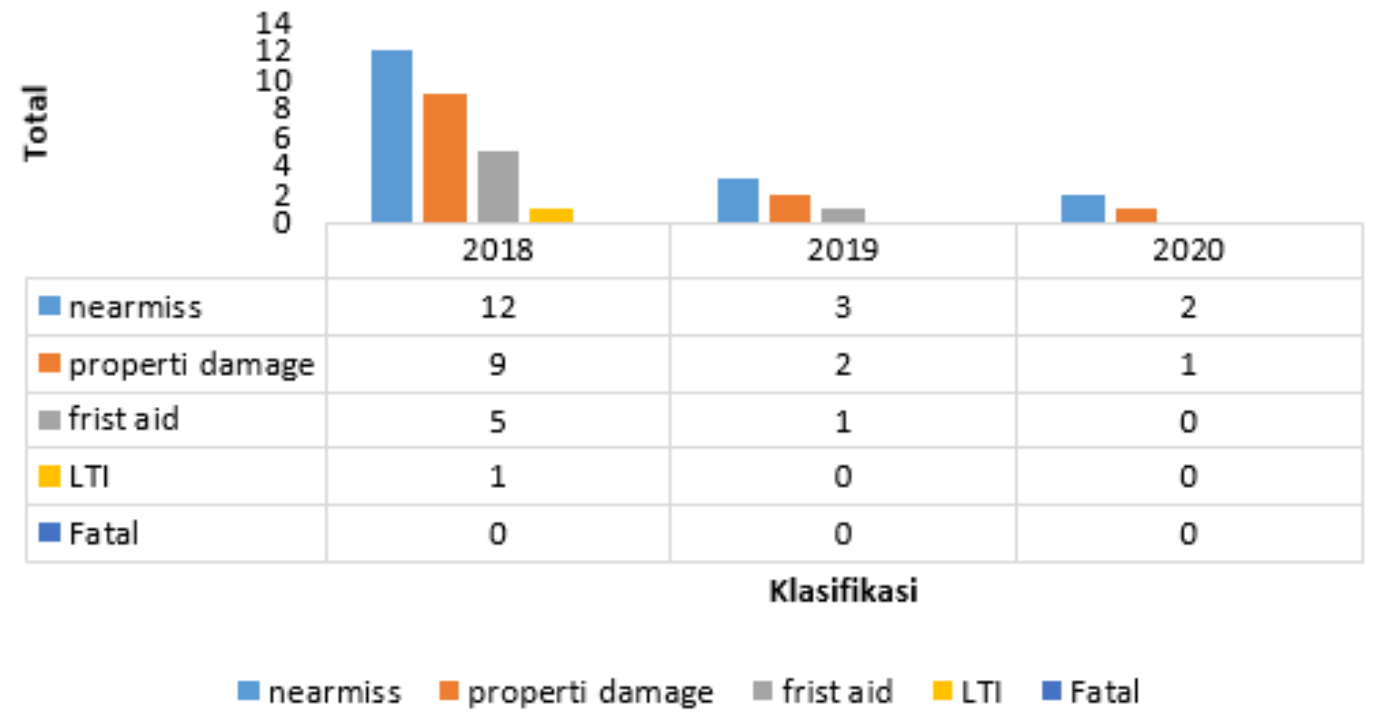

Gambar 6. Total insiden PT. X Tahun 2018-2020 
Langkah-langkah yang telah dilakukan pada kasus kecelakaan yang menimpa teknisi tersebut untuk dilakukan identifikasi pada kasus kecelakaan yang lain. Ini dimaksudkan agar setiap kecelakaan kerja ditemukan akan akar masalahnya dan kemudian ditentukan tindakan perbaikannya.

Dari perbaikan terus-menerus yang dilakukan mulai dari top management sampai karyawan, maka angka kecelakaan kerja dapat ditekan. Turunnya angka kecelakaan kerja tersebut dapat dilihat grafik gambar 6.

\section{SIMPULAN}

Berdasarkan penelitian dan perbaikan yang telah dilakukan Departemen Rebuild Center PT X maka secara umum dapat disimpulkan bahwa untuk kasus kecelakaan kerja yang menimpa teknisi ada tiga akar masalah yaitu: Pertama, validasi prosedur assembly turbocharger hanya dilakukan sampai pada tingkat pengawas belum sampai ke tingkat manajemen. Kedua, manajemen tidak menyadari penyebab fatigue atau kelelahan salah satunya kurang jam tidur. Ketiga, sistem sosialisasi pekerjaan terkait penggunaan APD pada di proses assembly turbocharger belum dilakukan secara sistematis. Selanjutnya, dari tindakan perbaikan terus-menerus yang dilakukan mulai dari top management sampai karyawan, maka angka kecelakaan kerja di Departemen Departemen Rebuild Center PT X.

\section{REFERENSI}

[1] UU RI Nomor 1 Tahun 1970Tentang Keselamatan Kerja, "Undang-undang Republik Indonesia Nomor 1 Tahun 1970 Tentang Keselamatan Kerja," Ann. Rep. vet. Lab. N. Engl. Zool. Soc. Chester Zool. Gard., 1970.

[2] P. K. Suma'mur, Hygiene Perusahaan Dan Kesehatan Kerja (Hiperkes). 2009.

[3] M. Di and L. Biologi, "EVALUASI PENERAPAN PRINSIP KESEHATAN DAN KESELAMATAN KERJA ( K3 ) PADA PELAKSANAAN KEGIATAN PRAKTIKUM.”

[4] B. Ketenagakerjaan, “Angka kecelakaan kerja di Indonesia," BPJSKetenagakerjaan, 2018.

[5] D. S. Setiawan, J. Langoy, D. T. Wibowo, and S. Suhernomo, "DARO ZERO ACCIDENT MINDSET (a-ZAM), STRATEGI MENUJU PENINGKATAN BUDAYA KESELAMATAN DAN KESEHATAN KERJA PT ADARO INDONESIA," Pros. Temu Profesi Tah. PERHAPI, 2019, doi: 10.36986/ptptp.v0i0.19.

[6] D. F. Nugroho, K. Yakin, and M. O. Bustamin, "Kajian Risiko Kecelakaan Kerja Terhadap Manajemen Kesehatan Dan Keselamatan Kerja (K3) (Proyek Pembangunan Villa Grand Sinensis PT.Wahana Karya Wijaya)," Ge-STRAM J. Perenc. dan Rekayasa Sipil, 2018, doi: 10.25139/jprs.v1i2.1210. 
[7] M. R. Jannah, S. El Unas, and M. H. Hasyim, "PADA STUDI KASUS PROYEK PEMBANGUNAN MENARA X DI JAKARTA ( Risk Analysis of Occupational and Safety Using HIRADC Approach and Job Safety Analysis Method in the Case Study of Tower Project X in Jakarta ),” Tek. Sipil, p. 9, 2014.

[8] S. Winarto, H. M. Denny, and B. Kurniawan, "Studi Kasus Kecelakaan Kerja pada Pekerja Pengeboran Migas Seismic Survey PT. X di Papua Barat,” J. Promosi Kesehat. Indones., 2016, doi: 10.14710/jpki.11.1.51-65.

[9] N. F. F. Henri Ponda, "Mitigasi Risiko Keselamatan Dan Kesehatan Kerja ( K3 ),” Din. Tek., vol. IX, no. 1, pp. 38-47, 2015.

[10] W. W. Arso, A. Domodite, and H. Sholih, "Menentukan Predictive Maintenance Pada Kerusakan Turbocharger Diesel Engine," J. Mech. Eng. Manuf. Mater. Energy, vol. 4, no. 1, pp. 50-59, 2020, doi: 10.31289/jmemme.v4i1.3757.

[11] W. A. Wolfe, "FAULT TREE ANALYSIS.," At. Energy Canada Limited, AECL, 1978, doi: 10.4018/978-1-4666-9717-1.les2.

[12] A. F. Mustika, M. H. Hasyim, and S. El Unas, "Analisa Keterlambatan Proyek Menggunakan Fault Tree Analysis(Fta) (Studi Kasus Pada Proyek Pembangunan Gedung Program Studi Teknik Industri Tahap II Universitas Brawijaya Malang)," J. Mhs. Jur. Tek. Sipil Univ. Brawijaya, 2014. 